\title{
ANALISIS PERSAMAAN MEREK TERKENAL YANG TIDAK SEJENIS DITINJAU DARI HUKUM MEREK (STUDI PUTUSAN MAHKAMAH AGUNG NOMOR 29 PK/PDT.SUS- HKI/2016)
}

\section{Arif Rohman}

Alumni Fakultas Hukum Universitas Islam Indonesia

Contact: arifrohman26@gmail.com

Diterima: 10 November 2021

Direvisi: -

Disetujui: 10 Desember 2021

Hak Cipta: (C)2018

Halaman: $27-46$

\begin{abstract}
The granting of a brand to a product of goods or services can also prevent unfair business competition, with the brand of a product or service being able to distinguish its origin, quality and guarantee that the product is original. A high-priced product is usually not because of the product itself, but the influence of the brand. In the case obtained by the author, the panel of judges is of the opinion that the lawsuit for the cancellation of the mark is not accepted because the goods in dispute are not of the same type. The Supreme Court argues that until now there has been no Government Regulation as a follow-up to Article 6 paragraph 2 of Law Number 15 of 2001 concerning Marks. Based on the plenary meeting of the civil chamber as outlined in the Circular Letter of the Supreme Court Number 03/BUA.6/HS/SP/XII/2015, it has been agreed that the lawsuit for the cancellation of a mark which has essentially different similarities, the lawsuit must be declared not accepted and the verdict -the previous Supreme Court decision regarding the same mark for goods of a different kind is no longer guided by the guidelines; is a cumulative-critical legal case study that is based on a collection of information, the existence of cause and effect to then draw conclusions; Based on the description of the legal analysis above, the authors draw two conclusions, namely: 1 . The decision of the Panel of Judges is not quite right. 2. The legal consequences of the Supreme Court's Decision Number 29 PK/Pdt.SusHKI/2016 which was decided with a verdict that cannot be accepted in the last legal effort of the PK, has permanent legal force.
\end{abstract}

Keywords: Brand Rights, Dissimilar Brand Rights. 


\section{PENDAHULUAN \\ Posisi Kasus}

Pemohon Peninjauan Kembali/Termohon Kasasi/Penggugat adalah salah satu produsen mobil terkenal dan terkemuka di dunia yang bernama BAYERISCHE MOTOREEN WERKE (BMW) selanjutnya disebut Penggugat, berada dalam peringkat 100 besar dari daftar perusahaan FORTUNE GLOBAL 500. Merek BMW menempati peringkat 12 teratas dari peringkat 100 besar merek Global Terbaik oleh salah satu agensi pemberi peringkat merek paling dihormati yaitu Interbrand. Lebih lanjut mobil-mobil penggugat telah digunakan dalam film-film Hollywood yang popular dan yang paling baru adalah film action Mission Impossible Four yang dibintangi oleh aktor Tom Cruise yang sangat terkenal.

Produksi kendaraan milik Penggugat dapat ditelusuri dari masa ke masa yaitu sejak tahun 1197 atas produksi sepeda motor dan setelahnya pada tahun 1928 memproduksi mobil. Pendaftaran pertama merek kata BMW terdaftar di Jerman pada tahun 1929 dan berlaku hingga 28 Februari 2019, jauh sebelum Tergugat mengajukan pendaftaran mereknya. Penggugat saat ini telah mendaftarkan merek BMW di lebih dari 150 negara termasuk Indonesia. Pendafta ran tersebut tidak hanya mendaftarkan kendaraan-kendaraan saja, tetapi juga barang fashion dan olahraga.

Penggugat juga memiliki banyak pendaftran untuk logo BMW yang terdiri dari desain lingkaran dengan bentuk dua bagian dari seperempat lingkaran berwarna putih yang dinyatakan menyerupai baling-baling yang berputar dengan latar belakang langit.
Pada tahun 2013 Penggugat menggugat Henrywo Yuwijono selanjutnya disebut Tergugat, ke Pengadilan Niaga pada Pengadilan Negeri Jakarta Pusat untuk pembatalan merek. BMW BODY MAN WEAR. Tergugat adalah pemilik merek BMW BODY MAN WEAR dengan nomor permohonan merek D00-2004- 0880608901 yang diajukan permohonan merek pada tanggal 3 Mei 2002, dan diperoleh nomor registrasi merek IDM000016513 pada tanggal 17 September 2004, di kelas 25 yaitu barang fashion. Kemudian pada tanggal 20 Oktober 2008 Tergugat mendafatarkan logo mereknya dan diperoleh nomor registrasi IDM000181631.

Gugatan pembatalan merek ini didasarkan pada ketentuan Pasal 68 UndangUndang Merek menyatakan bahwa: "Gugatan pembatalan pendaftaran Merek dapat diajukan oleh pihak yang berkepentingan berdasarkan alasan sebagaimana dimaksud dalam Pasal 4, Pasal 5, atau Pasal 6"; Bahwa gugatan pembatalan merek ini didasarkan pada Pasal-Pasal tersebut yang berbunyi:

1. Pasal 4 Undang-Undang Nomor 15 Tahun 2001 Tentang Merek berbunyi: Bahwa Tergugat mengajukan permohonan pendaftaran merek-merek dengan itikad tidak baik;

2. Pasal 6 ayat (1) huruf (b) UndangUndang Nomor 15 Tahun 2001 Tentang Merek berbunyi: Bahwa merek-merek milik Tergugat mempunyai persamaan pada pokoknya dan/atau pada keseluruhannya dengan merek terkenal "BMW" dan "LOGO BMW" yang dimiliki oleh Penggugat untuk barang yang sejenis;

3. Pasal 6 ayat (2) Undang-Undang Nomor 
15 Tahun 2001 Tentang Merek berbunyi: Bahwa merek-merek milik Tergugat mempunyai persamaan pada pokoknya dan/atau pada keseluruhannya dengan merek terkenal "BMW" dan "LOGO BMW" yang dimiliki oleh Penggugat untuk barang yang tidak sejenis.

Berdasarkan bukti-bukti dan alasan-alasan yang disampaikan Penggugat. Majelis hakim memutuskan BMW milik Penggugat terbukti sebagai merek terkenal dunia. Sedangkan BMW milik Tergugat dianggap memiliki iktikad tidak baik saat mendaftarkan merek Body Man Wear, karena mendompleng keternaran merek BMW Jerman yang sudah terkenal dan memerintahkan kepada Turut Tergugat yaitu Direktorat Jendral Hak Kekayaan Intelektual untuk melaksanakan pembatalan merek BMW milik Tergugat yang Termuat dalam Putusan Pengadilan Niaga pada Pengadilan Negeri Jakarta Pusat Nomor 50/Pdt.Sus/Merek/2013/PN Niaga Jkt. Pst. Atas Putusan Pengadilan Niaga pada Pengadilan Negeri Jakarta Pusat Nomor 50/Pdt.Sus/Merek/2013/PN Niaga Jkt. Pst,

Tergugat tidak terima dan mengajukan permohonan kasasi pada Mahkamah Agung dengan alasan bahwa pembatalan merek yang telah dilakukan oleh Penggugat telah kadaluwarsa, karena sudah melebihi batas waktu 5 tahun sejak berlakunya pelindungan merek BMW milik Tergugat, yaitu pada tahun 2002 dan tahun 2005 sedangkan gugatan pembatalanya dimohonkan pada tahun 2013, sesuai dengan ketentuan Pasal 69 ayat (1) Undang- Undang Nomor 15 Tahun 2001 tentang Merek. Majelis Hakim pada tingkat kasasi mengabulkan permohonan kasasi, dengan amar putusan Mahkamah Agung Nomor 79 K/Pdt,Sus-HKI/2014 pada tanggal 27 Oktober 2014 yang berisi Membatalkan Putusan Pengadilan Niaga pada Pengadilan Negeri Jakarta Pusat Nomor 50/Pdt.Sus/Merek/2013/PN Niaga Jkt. Pst.

Pengugat tidak terima dengan Putusan Kasasi dan kembali melakukan upaya hukum terakhir dengan mengajukan permohonan Peninjauan Kembali pada Mahkamah Agung. Tapi upaya tersebut justru tidak membuahkan hasil. MA hanya mengubah putusan ditolak menjadi tidak diterima, dengan Putusan Mahkamah Agung Nomor 29 PK/Pdt.Sus-HKI/2016.

Majelis hakim berpendapat bahwa gugatan pembatalan merek itu tidak diterima karena barang yang disengketakan tidak sejenis. Mahkamah Agung berargumen bahwa hingga sekarang belum ada Peraturan Pemerintah sebagai tindak lanjut dari Pasal 6 ayat 2 Undang-Undang Nomor 15 Tahun 2001 Tentang Merek. Berdasarkan rapat pleno kamar perdata yang di tuangkan dalam Surat Edaran Mahkamah Agung Nomor 03/BUA.6/H.S/SP/XII/2015, telah disepakati bahawa gugatan pembatalan merek yang memiliki persamaan pada pokoknya yang tidak sejenis, gugatan harus dinyatakan tidak diterima dan putusanputusan Mahkamah Agung terdahulu tentang merek yang sama untuk barang tidak sejenis tidak lagi dipedomani. (Putusan PK Mahkamah Agung Nomor 29 PK/Pdt.SusHKI/2016). 


\section{Amar Putusan}

Putusan Mahkamah Agung Nomor 29 PK/Pdt.Sus-HKI/2016:

\section{MENGADILI}

1. Mengabulkan permohonan peninjauan kembali dari Pemohon Peninjauan Kembali BAYERISCHE MOTOREEN WERKE AKTIENGESELOLSCHAFFT tersebut;

2. Membatalkan Putusan Mahkamah Agung Nomor 79 K/Pdt.Sus-HKI/2014 tanggal 27 Oktober 2014 juncto Putusan Pengadilan Niaga pada Pengadilan Negeri Jakarta Pusat Nomor 50/Pdt.Sus/Merek/2013/PN Niaga Jkt. Pst, tanggal 10 Desember 2013.

\section{MENGADILI KEMBALI}

1. Menyatakan gugatan Penggugat tidak dapat diterima;

2. Menghukum Termohon Peninjauan Kembali untuk membayar biaya perkara dalam semua tingkat peradilan dan pemeriksaan peninjauan kembali, yang dalam pemeriksaan peninjauan kembali sebesar Rp10.000.000.00 (sepuluh juta rupiah).

Demikianlah diputuskan dalam rapat permusyawaratan Majelis Hakim pada Mahkamah Agung pada hari Rabu, tanggal 11 Mei 2016 oleh Prof. Dr. Takdir Rahmadi, S.H., LLM., Hakim Agung yang ditetapkan oleh ketua Mahkamah Agung sebagai Ketua Majelis, I Gusti Agung Sumanatha, S.H., M.H., dan H. Hamdi, S.H., M.Hum., Hakim-Hakim Agung, masing-masing sebagai Anggota, Putusan tersebut diucapkan dalam sidang terbuka untuk umum pada hari itu juga oleh Ketua dengan dihadiri oleh Hakim-Hakim Anggotaa tersebut dan Endang Wahyu Utami, S.H., M.H., Panitera Pengganti tanpa dihadiri oleh para pihak..

\section{RUMUSAN MASALAH}

Berdasarkan rangkaian uraian di atas, maka penulis ingin mengkaji permasalahan pada Studi Kasus Hukum ini yaitu : 1. Bagaimana analisis terhadap pertimbangan Hakim Mengenai pembatalan persamaan merek terkenal yang tidak sejenis berdasarkan hukum merek?; 2. Bagaimanakah akibat hukum atas Putusan Mahkamah Agung Nomor 29 PK/Pdt.Sus-HKI/2016?

\section{TUJUAN PENULISAN}

1. Untuk memberikan analisis terhadap pertimbangan Hakim Mengenai pembatalan persamaan merek terkenal yang tidak sejenis berdasarkan hukum merek.

2. Untuk mengetahui akibat hukum atas Putusan Mahkamah Agung Nomor 29 PK/Pdt.Sus-HKI/2016.

\section{METODOLOGI}

Artikel ini merupakan penelitian studi kasus berdasarkan Putusan Mahkamah Agung Nomor 29 PK/Pdt.Sus-HKI/2016, yang bersifat kumulatif-kritis.

\section{HASIL DAN ANALISA HUKUM}

Sebelum membahas mengenai rumusan masalah, penulis akan memberikan deskripsi tentang pelindungan Hak Kekayaan Intelektual (HKI), dimana salah satu katagori HKI yang dilindungi adalah Hak Merek. Perlindungan hukum terhdapa karya intelektual dalam era globalisasi sangan penting dilakukan, mengingat begitu pesatnya kemajuan teknologi 
yang memungkinkan suatu karya intelektual. Pelanggaran HKI dapat berupa pembajakkan, pemalsuan dalam konteks hak cipta dan hak merek dagang serta pelanggaran hak paten. Semua pelanggaran tersebut jelas sangat merugikan secara signifikan bagi pelaku ekonomi. (Sutedi, 2009, hlm. 6).

Pentingnya akan pelindungan terhadap HKI, banyak dilakukan oleh negara membentuk konvensi-konvesi internasioanal yang mengatur tentang pelindungan HKI, salah satunya adalah Perjanjian TRIPs (Trade Realeted Aspect of Intellectual Property Rights Including Trade in Counterfeit). Perjanjian TRIPs mengatur tentang katagori yang termasuk dalam karya intelektual, yaitu sebagai berikut: (Sutedi, 2009, hlm. 56).

1. Hak Cipta dan Hak-Hak yang berkaitan dengan Hak Cipta (Copyrights and Related Rights);

2. Patents;

3. Merek Dagang (Trademarks);

4. Indikasi Geografis (Geographical Indication);

5. Desain Industri (Industrial Design);

6. Rahasia Dagang (Protection of Undisclosed Informatioan);

7. Desain Tata Letak Sirkuit Terpadu (Layout-Desing of Intergrated Circuits);

8. Control of Anti Competitive Practices in Contractual.
Konsekuensi keikutsertaan Indonesia menjadi anggota World Trade Organization (WTO) dan konsekuensi dari perjanjian TRIPs, Indonesia diwajibkan menyesuaikan perundang-undangan domestiknya dibidang HKI dengan standar minimum yang telah diatur dalam TRIPs. Pelindungan HKI ini menjadi lebih dari sekedar keharusan setelah dicapainya kesepakatan GATT (General Agreement on Tariff and Trade) dan setelah Konferensi Marakesh pada bulan April 1994 disepakati pula GATT akan diganti dengan sisitem perdagangan dunia yang sekarang dikenal dengan WTO (World Trade Organization) yang diratifikasi oleh pemerintah Indonesia melalui Undang-Undang Nomor 7 Tahun 1994 tentang pengesahan Agreement Establishing The World Trade Organization atau Persetujuan Pembentukan Organisasi Perdagangan Dunia. Saidin, 2015).

Selanjutnya, melalui ratifikasi tersebut, Pemerintah Indonesia mengeluarkan beberapa aturan dibidang HKI diantaranya adalah Undang-Undang Nomor 20 Tahun 2016 tentang Perubahan Kelima atas UndangUndang Nomor 15 Tahun 2001 tentang Merek, Undang-Undang Nomor 13 Tahun 2016 tentang Hak Paten, Undang-Undang Nomor 19 Tahun 2002 tentang Hak Cipta dan sebagainya yang masing-masing memiliki perbedaan, namun mempunyai tujuan yang sama yaitu untuk melindungi karya intelektual. 
Merek merupakan bagian dari Hak Kekayaan Intelektual yang dilindungi oleh undangundang, diantaranya adalah Undang-Undang Nomor 20 Tahun 2016 tentang Perubahan Kelima atas Undang-Undang Nomor 15 Tahun 2001 tentang Merek. Secara umum pengertian merek menurut World Intelectual Property Organization (WIPO) adalah merek sebagai tanda yang dapat membedakan barang atau jasa dari suatu perusahaan dengan perusahaan lainnya. Sementara, dalam perjanjian Internasional, istilah merek didefinisikan dalam Pasal 15 ayat (1) Perjanjian TRIPs, yaitu:

"Setiap tanda atau kombinasi tanda yang dapat membedakan barang atau jasa dari perusahaan satu dengan perusahaan lain harus dapat dijadikan merek. Tanda dimaksud, khususnya kata, termasuk nam personal, huruf-huruf, unsur figurative dan kombinasi warna dan juga kombinasi tanda tersebut, harus memenuhi syarat pendaftaran merek. Jika suatu tanda tidak mampu membedakan barang atau jasa yang berkaitan, negara anggota dapat mendaftarkan tanda tersebut berdasarkan daya pembeda yang didapatkan karena penggunaan. Negara anggota dapat menambahakan sebagai syarat pendaftaran bahwa tanda tersebut harus tampak secara visual."
Pengertian merek yang diatur dalam Perjanjian TRIPs menyatakan setiap tanda atau kombinasi dari tanda-tanda disertai dengan contoh nama, huruf-huruf, warna-warna dan sebagainya. Namun demikian, ketentuan itu tidak membatasi pelindungan merek untuk tanda dalam bentuk lain yang tidak tercantum dalam definisi tersebut sepanjang memiliki daya pembeda. Perjanjian TRIPs pada hakikatnya hanya merupakan seprangkatan aturan minimum di bidang HKI yang wajib diratifikasi oleh setiap anggota WTO. (Indriyanto \& Yusnita, 2017).

Pasal 1 ayat (1) Undang-Undang Nomor 15 Tahun 2001 tentang Merek, deifinisi merek berbunyi: "Merek adalah tanda yang berupa gambar, nama, kata, huruf-huruf, angkaangka, susunan warna, atau kombinasi dari unsurunsur tersebut yang memiliki daya pembeda dan digunakan dalam kegiatan perdagangan barang atau jasa.”

Sedangkan Pasal 1 ayat (1) Undang-Undang Nomor 20 Tahun 2016 tentang Merek dan Indikasi Geografis, menyebutkan merek yaitu: "Merek adalah tanda yang dapat ditampilkan secara grafis berupa gambar, logo, nama, kata, huruf, angka, susunan warna, dalam bentuk 2 (dua) dimensi dan/atau 3 (tiga) dimensi, suara, hologram, atau kombinasi dari 2 (dua) atau lebih unsur tersebut untuk membedakan barang dan/atau jasa yang diproduksi oleh 
orang atau badan hukum dalam kegiatan perdagangan barang dan/atau jasa..”

Hak Merek berdasarkan Pasal 3 UndangUndang Nomor 15 Tahun 2001 tentang Merek, memberi penjelasan bahwa: "Hak atas Merek adalah hak eksklusif yang diberikan oleh Negara kepada pemilik Merek yang terdaftar dalam Daftar Umum Merek untuk jangka waktu tertentu dengan menggunakan sendiri Merek tersebut atau memberikan izin kepada pihak lain untuk menggunakannya."

Sedangkan Hak Merek berdasarkan undangundang baru tentang Merek dalam Pasal 1 ayat (5) Undang-Undang Nomor 20 Tahun 2016 tentang Merek dan Indikasi Geografis, yaitu: "Hak atas Merek adalah hak eksklusif yang diberikan oleh negara kepada pemilik Merek yang terdaftar untuk jangka waktu tertentu dengan menggunakan sendiri Merek tersebut atau memberikan izin kepada pihak lain untuk menggunakannya."

Berdasarkan penjelasan Hak Merek di atas maka hak atas merek tercipta karena pendaftaran dan bukan karena pemakaian pertama. Jelas disini menggunakan sistem konstitutif karena lebih terwujudnya kepastian hukum. Jadi, Hak ini adalah suatu hak yang eksklusif artinya orang lain tidak dapat memakai merek yang sama. Sehingga merek yang sudah didaftarkan akan mendapatkan pelindungan hukum bagi orang atau badan usaha yang mendaftarkannya.

Merek juga memiliki beberapa jenis, sebagaimana tercantum pada Pasal 1 butir 2 dan 3 Undang-Undang Nomor 15 Tahun 2001 tentang Merek, yaitu merek dagang dan merek jasa. Merek dagang adalah merek yang digunakan pada barang yang diperdagangkan oleh seseorang atau beberapa orang secara bersama-sama atau badan hukum untuk membedakan dengan barang-barang sejenis lainnya. Sedangkan merek jasa merupakan merek yang digunakan pada jasa yang diperdagangkan oleh seseorang atau beberapa orang secara bersama-sama atau badan hukum untuk membedakan dengan jasa-jasa sejenis lainnya.

Selain jenis merek yang dijelaskan di atas ada pula pengklasifikasian lain yang didasarkan pada bentuk dan wujudnya. Menurut Suryatin bentuk dan wujud merek dimaksudkan untuk membedakan dari barang sejenis milik orang lain. Maka dari itu terdapat beberapa jenis merek yaitu:
1. Merek lukisan (beel mark)
2. Merek kata (word mark)
3. Merek bunyi-bunyi (klank mark)
4. Merek bentuk (form mark)
5. $\quad$ Merek judul (title mark)

Prof. R. Soekardono mengemukakan pendapatnya bahwa, tentang bentuk dan wujud dari merek itu undang-undang tidak 
memerintahkan apa-apa, melainkan harus berdaya pembeda, yang diwujudkan dengan: 1) Cara yang oleh siapa pun mudah dapat dilihat (beel mark), 2) Merek dengan perkataan (word mark), 3) Kombinasi dari merek atas pengelihatan dan merek perkataan.

Disamping itu saat ini dikenal juga merek dalam bentuk tiga dimensi seperti merek pada produk minuman Coca-Cola dan Kentucky Fried Chicken. Selain jenis-jenis merek yang telah dikemukakan oleh para ahli diatas. Dilihat dari prilaku merek di perdagangan bebas, banyak ahli yang berpendapat terjadinya perbedaan kemasyhuran atau tingkat keterkenalan yang dimiliki merek menjadi tiga jenis yaitu: (Gunawati, 2015).

\section{Merek Biasa}

Merek biasa (normal mark) adalah merek yang tidak dianggap memiliki reputasi tinggi. Merek yang berderajat biasa dianggap kurang memeberi pancaran simbolis gaya hidup baik dari segi pemakaian dan teknologi. Masyarakat dan konsumen melihat kualitasnya rendah, pemakainnya tidak efisien, desain kurang memenuhi selera. Jika seseorang hendak membeli barang jenis tersebut, tidak langsung masyarakat konsumen menentukan pilihan terhadapnya, kemungkinan jenis barang yang memakai merek seperti itu, akan jatuh menjadi pilihan terakhir, walaupun mungkin harganya sangat murah dibandingkan dengan harga barang yang sama jenisnya.

\section{Merek Terkenal}

Ada yang lebih tinggi dari merek biasa yaitu merek yang mempunyai kedudukan terkenal atau "well-known mark". Merek ini menjadi idaman dan pilihan utama semua lapisan konsumen. Merek idaman dan pilihan utama semua lapisan konsumen. Merek ini menjadi symbol yang memiliki "reputasi tinggi". Lambangnya memeiliki kekuatan pancaran yang memukau dan menarik, sehingga jenis barang apa saja yang berada di bawah merek itu, langsung menimbulkan sentuhan keakraban (familiar attachment) dan ikatan mitos (mythical context) kepada semua lapisan konsumen.

\section{Merek Termasyhur}

Tingkat derajat merek yang tertinggi ialah merek termasyhur atau "famous mark". Sedemikian rupa masyhurnya diseluruh dunia, sehingga reputasinya digolongkan "merek aristocrat dunia". Ada beberapa istilah yang dipergunakan untuk menamai merek termasyhur. Ada yang menyebutnya "highly renowed" merupakan "superlative" dari "well-known". Artinya, merek termasyhur mempunyai derajat yang lebih tinggi dari derajat merek biasa (normal 
mark). Oleh karena itu, merek termasyhur dianggap sangat utama kedudukanya (parexcellent) dibanding dengan derajat merek biasa maupun merek terkenal. Itu sebabnya merek termasyhur dianggap mempunyai reputasi yang sangat tinggi derajatnya atau "highly degree of reputation".

Untuk mendapatkan hak eksklusif dan pelindungan hukum suatu merek sesorang atau badan hukum harus mendaftarkan mereknya terlebih dahulu sesuai syarat dan ketentuan yang berlaku. Ketentuan yang terkait dengan syarat pendaftaran merek diatur dalam Undang-Undang Nomor 20 Tahun 2016 tentang Merek dan Indikasi Geografis dalam bab tentang permohonan pendaftaran merek, ketentuan tersebut menyederhanakan syarat permohonan merek dalam UndangUndang Nomor 15 Tahun 2001 tentang Merek. Dalam Pasal 13 Undang-Undang Nomor 20 Tahun 2016 tentang Merek dan Indikasi Geografis disebutkan bahwa tanggal penerimaan permohonan diberikan apabila permohonan tersebut memenuhi persyaratan minimum yang berupa formulir permohonan yang telah diisi lengkap dengan label merek dan bukti pembayaran biaya permohonan. Ketentuan ini berbeda dengan ketentuan yang ada pada undang-undang sebelumnya yang juga mencantumkan surat pernyataan dan surat kuasa sebagai syarat minimum pendaftaran.
Dengan kata lain, kekurangan dokumen surat pernyataan dan surat kuasa tidak akan mengubah tanggal penerimaan permohonan. (Indriyanto \& Yusnita, 2017).

Untuk lebih jelasnya Prof. Mr. Dr. Sudargo Gautama dan peraturan merek memberikan penjelasan tentang merek yang tidak bisa digunakan atau tidak dapat didaftarkan sebagai merek yaitu: (Saidin, 2015).

1. Bertentangan dengan kesusilaan dan ketertiban umum

Tanda-tanda yang bertentangan dengan kesusilaan dan ketertiban umum tidak dapat diterima sebagai merek. Merek bersangkutan tidak boleh terdapat lukisanlukisan, gambar atau kata-kata yang bertentangan dengan kesusilaan yang baik dan ketertiban umum.

Di dalam lukisan-lukisan ini kiranya tidak dapat pula dimasukkan berbagai gambarangambaran yang dari sisi keamanan atau sisi penguasa tidak dapat diterima karena diliahat dari sisi kesusilaan maupun dari sisi politis dan ketertiban umum. Lukisanlukisan yang tidak memenuhi norma-norma atau kata-kata yang terdapat dalam sesuatu yang diperkenankan sebagai merek dapat menyinggung atau melanggar perasaan, kesopanan, ketentraman atau keagamaan, baik dari khalayak umum maupun suatu 
golongan masyarakat tertentu.

2. Tanda-tanda yang tidak mempunyai daya pembeda

Tanda-tanda yang tidak mempunyai daya pembeda atau yang dianggap kurang kuat dalam pembedaannya tidak dapat dianggap sebagai merek. sebagai contoh misalnya dapat diberitahukan disini: lukisan suatu sepeda untuk barang-barang sepeda atau kata-kata yang menunjukkan suatu sifat barang, seperti "istimewa". "super", "sempurna". Semua ini menunjukan pada kulitas suatu barang. Juga nama barang itu sendiri tidak dipakai sebagai merek. misalnya "kecap" untuk barang kecap, merek "sabun" untuk barang sabun dan sebagainya. Misalnya perkataan "super" itu menunjukan suatu kualitas atau mempropagandakan kualitas barangnya, maka tidak mempunyai cukup daya pembedaan untuk diterima sebagai merek.

\section{Tanda milik umum}

Tanda-tanda yang karena telah dikenal dan dipakai secara luas serta bebas di kalangan masyarakat tidak lagi cukup untuk dipakai sebagai tanda pengenal bagi keperluan pribadi dari orang-orang tertentu. Misalnya disimpulkan di dalam katagori ini tanda lukisan mengenai "tengkorak manusia dengan dibawahnya ditarunya tulang bersilang", yang secara umum dikenal dan juga dalam dunia internasional sebagai tanda bahaya racun. Kemudian tidak dapat juga dipakai merek suatu lukisan tentang "tangan yang dikepal dan ibu jari keatas", yang umum dikenal sebagai suatu tanda pujian atau "jempol”. Kemudian juga dapat dianggap sebagai milik umum misalnya perkataan "Pancasila" dan sebagainya.

4. Merupakan keterangan atau berkaitan dengan barang atau jasa yang dimintakan pendaftaran

Selanjutnya yang dimaksud dengan merupakan keterangan atau berkaitan dengan barang atau jasa yang dimintakan pendaftaran seperti merek "kopi atau gambar kopi" untuk produk kopi. Contoh lain misalnya merek "mobil atau gambar mobil" untuk produk mobil ini maksudnya agar pihak konsumen tidak keliru, sebab jika hal itu dibenarkan ada kemungkinan orang lain akan menggunakan merek yang sama oleh orang lain akan menggunakan merek yang sama oleh karena bendanya, produknya atau gambarnya sama dengan mereknya.

5. Merek yang memuat unsur yang dapat menyesatkan masyarakat

Unsur yang dapat menyesatkan masayarakat tentang asal, kualitas, jenis, 
ukuran, macam, tujuan penggunaan barang atau jasa dan merek yang memuat keterangan yang tidak sesuai dengan kualitas, manfaat, atau khasiat dari barang dan jasa yang diproduksi. Contoh merek yang memuat unsur menyesatkan antara lain merek "Kecap Nomor 1" yang tidak dapat didaftarkan karena menyesatkan masyarakat terkait dengan kualitas barang. Contoh lainnya dalah merek "netto 100 gram" juga tidak dapat didaftarkan karena menyesatkan masyarakat terkait dengan ukuran barang. Sementara untuk contoh merek yang mencantumkan keterangan yang tidak benar atau tidak sesuai dengan kualitas, manfaat, khasiat atau resiko dari produk, misalnya merek yang mencantumkan keterangan obat yang dapat menyembuhkan seribu satu penyakit atau rokok yang aman bagi kesehatan

6. Merek yang merupakan nama varietas tanaman yang dilindungi

Nama varietas tanaman yang dilindungi ada yang memohonkan untuk di daftarkan sebagai merek untuk barang atau jasa yang sejenis pendaftaranya harus ditolak. Rasionalitas penolakan permohonan pendaftran merek jika suatu merek merupakan nama varietas tanaman yang dilindungi untuk barang atau jasa sejenis adalah karena nama varietas tanaman merupakan nama lain atau berkaitan dengan barang dan jasa yang dimohonkan pendaftaranya. Dengan kata lain, nama varietas tanaman bisa dikatagorikan sebagai kata generik atau deskriftif untuk barang dan jasa tertentu sehingga tidak dapat berfungsi sebagai merek yang membedakan antara produk yang satu dengan produk lainnya. Sebagai contoh, nama varietas tanaman "Padi Pandan Wangi" merupakan kata yang bersifat generik untuk produk tanaman padi atau beras (jenis pandan wangi) sehingga tidak dapat didaftarkan sebagai merek produk.

Ada tiga alasan dalam syarat merek yang tidak boleh dipakai dan didaftarkan. Pertama, untuk memberikan kepastian hukum bahwa suatu merek harus memiliki fungsi pembeda, yaitu dapat membedakan barang atau jasa dari satu produsen dengan produsen lain. Kedua, tanda yang bersifat umum dikecualikan dari kepemilikan yang eksklusif oleh satu pihak, sehingga dapat digunakan dengan bebas oleh semua pihak yang berkompetensi. Ketiga, tanda yang digunakan sebagai merek harus tidak boleh menimbulkan keresahan di masyarakat sehingga dapat mengganggu ketertiban umum. (Indriyanto \& Yusnita, 2017).

Merek dinilai memeiliki persamaan secara keseluruhan apabila tampilan seluruh unsur 
merek tersebut identik dengan merek lain tanpa ada modifikasi atau penambahan unsur lain. Jika pun ada perebedaan maka perbedaan tersebut tidak tamapk signifikan sehingga konsumen tidak akan mengangapnya sebagai identitas produk. Permohonan merek demikian akan di tolak karena dipastikan dapat menimbulkan kebingungan pada masyarakat dalam mengidentifikasi sumber produk. Konsumen akan berasumsi bahwa kedua merek saling terkait dan dimiliki oleh pihak yang sama. (Indriyanto \& Yusnita, 2017).

Selanjutnya yang dimaksud dengan persamaan merek pada pokoknya adalah kemiripan yang disebabkan oleh adanya unsur-unsur yang menonjol antara merek yang satu dengan merek lain, yang dapat menimbulkan kesan adanya persamaan baik mengenai bentuk, cara penempatan, cara penulisan atau kombinasi antara unsur-unsur atau pun persamaan bunyi ucapan yang terdpat dalam merek tersebut.

Ada tiga bentuk penggunaan merek yang dapat dikatagorikan persamaan pada pokoknya yakni:

1. Similarity in appearance confusing in appearance. Contohnya $=\mathbf{\Delta}=$

2. Similarity in sound $=$ confusion when pronounced.

3. Similarity in concept $=$ the meaning is so similar that you recall the same thing $*=$ star.
Adapun doktrin yanga menjelasakan mengenai persamaan merek pada pokoknya atau keseluruhan. Makna yang mendasar dalam doktrin ini. Memakai, mengambil atau meniru merek orang lain yang sudah terdaftar, di mana merek tersebut "sangat identik" atau "hampir mirip" diskripsinya dengan merek orang lain, maupun mempunyai "kemiripan yang sangat dekat" dengan merek orang lain yang sudah terdaftar, dianggap merupakan tindakan pengacauan dan penyesatan serta persaingan curang. (Harahap, 1996).

Kemudian mengenai pengertian barang dan jasa sejenis dan tidak sejenis, menurut praktik hukum merek, barang-barang adalah sejenis, jika dipandang dari sudut teknik dan perokonomian barang tersebut sedemikian dekat hubunganya, hingga jika barang-barang itu dipakai dengan merek-merek yang sama atau mirip, orang-orang mengambil kesimpulan tentang persamaan tempat asal barang-barang itu.

Dalam menentukan apakaha brang-barang itu adalah sejenis perlu diperhatikan persamaan sifat atau susuanannya, persamaan tempat, persamaan cara pembuatannya serta juga penjualannya. Kemudian persamaan tujuan pemkainya, apakah tujuan pemakaiannya itu dapat mengecohkan konsumen atau merupakan persaingan tidak wajar atau menarik manfaat dari merek orang lain yang 
sudah terkenal.

Penentuan barang sejenis dan tidak sejenis antara suatu barang dengan barang yang lain tidak dapat ditentukan secara pasti, apalagi dalam suatu perdagangan dan industri yang demikian pesat. Dalam menentukan barangbarang yang termasuk sejenis dan tidak sejenis harus diperhatikan pendapat umum, terutama dari golongan-golongan yang bersangkutan dengan barang-barang tersebut, apakah akan dapat menimbulkan kekeliruan dalam masyarakat tentang asal-usul dan produksi dari barang-barang yang bersangkutan.

Selama ini banyak pendapat yang menyatakan bahawa barang-barang adalah sejenis apabila tedapat di dalam satu kelas barang, dan sebaliknya barang-barang adalah tidak sejenis apabila tidak dalam satu kelas barang. Anggapan tersebut tentu saja tidak tepat. Pembagian barang-barang dalam kelas-kelas barang dibuat untuk keperluan perhitungan jumlah biaya pemeriksaan, yang ditetapkan menurut jumlah barang. Dengan demikian, penetapan barang-barang yang sejenis tidak bergantung pada pembagian dalam kelas-kelas barang. Dalam satu kelas barang mungkin termasuk beberapa barang mungkin termasuk beberapa jenis dan sebaliknya barang-barang yang sejenis tidak selalu termasuk dalam satu kelas barang.

Secara internasional terdapat penentuan daripada kelas-kelas barang ini. Klasifikasi barang di Indonesia menurut Peraturan Pemerintah Tentang Kelas Barang atau Jasa bagi Pendaftaran Merek, telah sejalan dengan klasifikasi internasional yang diatur dalam Nice Agreement tanggal 15 Juni 1957, Tentanag International Classification of Goods and Services for the Purposes of the Registration of Marks. Klasifikasi barang dan jasa ini terdiri dari 34 kelasa barang dan 8 jasa, tetapi untuk keadaan di Indonesia ditambahkan 1 kelas khusus, yaitu kelas 35 yang terdiri atas barang-barang khas Indonesia seperti kecap, tauco, terasi, petis, kerupuk dan emping.

TRIPs mengatur mengenai barang dan jasa tidak sejenis diatur dalam Pasal 16 ayat (3) yang menyatakan: "Pasal 6 bis Konversi Paris (1967) juga akan berlaku, secara mutatais dan mutandis untuk barang atau jasa yang tidak serupa (not similar). Berkaitan dengan perlindungan merek terkenal barang dan jasa tidak sejenis terdapat kriteria yaitu jika terdapat kesan keterkaitan yang erat/indikasi adanya suatu hubungan/confusion of business connection antara barang dan jasa yang menggunakan merek tersebut dengan produsenya."

Hal tersebut merupakan pertimbangan untuk menentukan apakah merek yang sama dengan merek terkenal tatapi didaftarkan untuk barang dan jasa tidak sejenis. (Gunawati, 2015). 
Berdasarkan rumusan Pasal 16 ayat (3) TRIPs disebutkan bahwa Pasal 6 bis Konvensi Paris (1967) juga akan berlaku, secara mutatis mutandis untuk barang atau jasa yang tidak serupa (not similar). Berhubung Indonesia telah menjadi pihak Paris Convention for the Protection of Intellectual Property, yang telah diratifikasi berdasarkan Keputusan Presiden Nomor 24 Tahun 1979 yang disertai persyaratan terhadap Pasal 1 sampai dengan Pasal 12 dan Pasal 28 ayat (1).

adanya ketentuan Pasal 16 ayat (3) TRIPs, berarti kelemahan yan ada dalam ketentuan Pasal 6 bis Konvensi Paris (1967) dapat diatasi, yaitu pelindungan merek terkenal tidak hanya mencakup barang dan jasa sejenis saja, tetapi juga meliputi barang dan jasa tidak sejenis. Bahkan, dalm Pasal 6 bis ayat (3) Konvensi Paris dijadikan prinsip atau asas penting, yaitu tidak ada jangka waktu yang ditentukan untuk melakukan permohonan pembatalan merek atau larangan untuk memmakai merek terdaftar jika dipakainya dengan itikad tidak baik.

Berkaitan dengan pemakaian merek terkenal untuk barang dan jasa tidak sejenis, Pasal 16 ayat (3) TRIPs disebutkan lebih lanjut bahwa "jika terdapat kesan keterkaitan yang erat" antara barang dan jasa yang menggunakan merek tersebut dengan produsenya, maka akan memeberikan indikasi adanya suatu hubungan antara barang-barang dan jasa pemilik daripada pihak merek terdaftar. Dengan demikian, terlihat bahwa pada Pasal 16 ayat (3) TRIPs terdapat "confusion of business connection" yang merupakan salah satu pertimbangan untuk menentukan apakah merek yang sama dengan merek terkenal, tetapi didaftarkan untuk barang dan jasa tidak sejenis harus ditolak dan dibatalkan tentang permohonan pendaftran merek, tentang permohonan perpanjangan merek pendaftaran yang telah terdaftar dan tentang pengalihan hak atas merek. (Gunawati, 2015).

Kasus sengketa merek antara BMW (BAYERISCHE MOTOREEN WERKE) sebagai Penguggat dan BMW (BODY MAN WEAR) sebagai Tergugat, Putusan Peninjauan Kembali Mahkamah Agung Nomor 29 PK/Pdt.Sus-HKI/2016 tanggal 11 Mei 2016, Mahkamah Agung Republik Indonesia Mengabulkan gugatan penggugat dari Pemohon Peninjauan Kembali BMW (BAYERISCHE MOTOREEN WERKE) dengan amar putusan tidak dapat diterima dan membatalkan Putusan Mahkamah Agung Nomor 79 K/Pdt.Sus-HKI/2014 tanggal 27 Oktober 2014 juncto Putusan Pengadilan Niaga pada Pengadilan Negeri Jakarta Pusat Nomor 50/Pdt.Sus/Merek/2013/PN Niaga Jkt. Pst, tanggal 10 Desember 2013.

Dalam pertimbangannya Hakim berpendapat 
bahwa dalam rapat pleno kamar perdata yang menghasilkan SEMA, untuk kasus sengketa merek yang memiliki persamaan pada pokoknya atau keseluruhannya untuk barang tidak sejenis amar putusannya adalah tidak dapat diterima. Hakim beralasan bahwa belum ada peraturan yang mengatur sehingga dianggap belum ada pelanggaran.

Jika dilihat dari kasus ini jelas terlihat ada iktikad tidak baik atau bad faith dalam pendaftaran merek yang dilakukan oleh BMW milik Tergugat yang memproduksi barang fashion untuk melakukan persaingan tidak sehat dalam bisnis, walaupun jenis produk yang dipasarkan beda kelas atau beda jenis. Dalam hal ini seharusnya Dirjen HKI menolak pendaftaran yang dilakukan oleh Tergugat untuk merek BMW miliknya. Karena untuk merek BMW sudah didaftarakan terlebih dahulu oleh BAYERISCHE MOTOREEN WERKE (BMW) perusahaan otomotif dan juga memiliki produk fashion yang berasal dari Jerman, bahkan merek BMW ini termasuk merek terkenal global terbaik yang menduduki peringkat ke 12 teratas dari 100 peringkat.

BMW milik Penggugat sendiri sudah terdaftar sejak tahun 1929, Pendaftaran pertama merek BMW di Jerman terdaftar di bawah Pendaftaran Nomor 410579 pada 15 November 1929 dan berlaku hingga 28 Februari 2019 untuk barangbarang di Kelas 07 dan 12. Merek BMW Penggugat juga telah terdaftar di lebih 150 negara termasuk Indonesia. Pendaftaran pertama untuk BMW LOGO di Jerman setidaknya sejak tahun 1917 dan/atau jauh sebelum Tergugat mengajukan permohonan pendaftaran mereknya, sedangkan merek BMW Tergugat baru pada tahun 2004 mereknya terdaftar.

Jika merujuk pada ketentuan dalam UndangUndang Nomor 15 Tahun 2001 Tentang Merek, sistem perolehan hak merek yang berkaitan dengan perlindungan hak merek adalah sistem konstitutif, yang mana yang memeiliki hak atas merek adalah yang mendaftarkan merek tersebut terlebih dahulu, maka dari itu yang memiliki hak untuk menggunakan merek BMW adalah Penggugat. Selain itu merek BMW milik penggugat adalah merek terkenal, yang sudah terbukti didaftarkan dilebih 150 negara, kemudian juga promosi yang gencar, sehingga masyarakat luas mengenal merek BMW milik pengugat.

Merek terkenal berhak atas perlindungan hukum meskipun belum terdaftar di suatu negara. Dengan demikian merek terkenal memperoleh perlindungan hukum khusus yang lebih luas. Pada hakikatnya, perlindungan tersebut ditunjukan terhadap goodwill atau reputasi yang melekat pada suatu merek karena proses upaya untuk menghasilkan reputasi yang secara hukum patut dihargai, 
dengan begitu andai saja BMW milik Pengguat tidak terdaftar di Indonesia akan tetap dilindungi oleh hukum karena keterkenalanya dan reputasi yang diperolehnya. Apalagi sudah terdaftar seharusnya negara dapat lebih leluasa untuk melindungi merek BMW. (Kurnia, 2011).

\section{Dalam Pasal 16 (2) dan (3) Perjanjian TRIPs} memperluas ruang lingkup Pasal 6 bis dari Konvensi Paris, berdasarkan peraturan ini , setiap merek terkenal harus dilindungi oleh hukum walaupun beda jenisnya, terlebih lagi merek tersebut sudah mendunia. Sehingga sudah jelas negara yang turut menjadi anggota terikat dengan peraturan ini. Sehingga merek yang sama dengan merek terkenal walaupun tidak sejenis harus ditolak pendaftaranya. Kemudian jika ada gugatan pembatalan merek terkenal yang sama pada pokoknya atau keseluruhan untuk barang tidak sejenis seharusnya majelis hakim mengabulkan gugatan dan membatalkan merek Tergugat dengan dasar iktikad tidak baik atau bad faith untuk mendompleng merek terkenal pihak lain. (Kaligis, 2012).

Menurut Bodenhausen, pembeda antara bad faith dan good faith harus dilihat dari apakah pihak yang mendaftarkan mereknya itu mengetahui flain, apakah merek tersebut sudah pernah didaftarkan atau tidak sebelumnya. Dengan demikian apabila seseorang mendaftar suatu merek yang dipersengketakan mengetahui sebelumnya bahwa merek terkenal telah didaftarkan oleh pemegang merek terkenal, berarti orang yang mendaftar setelahnya melakukan perbuatan iktikad tidak baik. (Gunawati, 2015).

Kemudian dalam Pasal 4 Undang-Undang Nomor 15 Tahun 2001 yang menyebutkan bahwa : "Merek tidak dapat didaftarkan atas dasar Permohonan yang diajukan oleh Pemohon yang beritikad tidak baik."

Berdasarkan penjelasan dalam Pasal 4 Undang-Undang Nomor 15 Tahun 2001, yang dimaksud dengan Pemohon yang beriktikad baik adalah Pemohon yang mendaftarkan merkenya secara layak dan jujur tanpa ada niat apapun untuk membonceng, meniru atau menjiplak ketenaran merek pihak lain atau menimbulkan kondisi persaingan usaha tidak sehat, mengecoh atau menyesatkan konsumen. Contohnya, merek dagang A yang sudah dikenal masyarakat secara umum sejak betahun-tahun, ditiru sedemikian rupa, sehingga memiliki persamaan pada pokoknya atau keseluruhannya dengan merek dagang $\mathrm{A}$ tersebut. Dalam contoh itu sudah terjadi iktikad tidak baik dari peniru karena setidaktidaknya patut diketahui unsur kesengajannya dalam meniru merek dagang yang sudah terkanal. (Gunawati, 2015).

Asas fundamental dalam rangka perlindungan 
hukum merek terkenal yang berlaku secara universal ialah bahwa senantiasa dan selfevident, terdapat atau terkandung unsur iktikad tidak baik jika terjadi persamaan pada pokoknya atau pada keseluruhanya antara suatu merek dengan merek terkenal. Asas ini disebut sebagai asas praduga iktikad tidak baik. Pihak yang melakukan itu pasti memiliki iktkad tidak baik untuk membonceng ketenaran atau membajak dasarnya selalu dengan iktikad tidak baik, kepada pembonceng atau pembajak tidak memperoleh perlindungan hukum. Hasil dari perbuatanya tidak boleh dimilikinya, asas demikian disebut pirate non mutat dominium. (Kurnia, 2011).

Dalam kasus ini jelas ada iktikad tidak baik yang dilakukan oleh Tergugat, untuk mendompleng ketenaran merek BMW milik Penggugat. Hal itu dapat dibuktikan dari nama, pengucapan dan bentuk logo merek BMW milik Tergugat megandung persamaaan pada pokoknya dengan Merek BMW milik Penggugat, seolah ada keterkaitan antara merek BMW milik Penggugat dan Teguggat, sehingga dapat menyesatkan konsumen. Berikut gambar logo merek BMW milik Penggugat dan Tergugat:

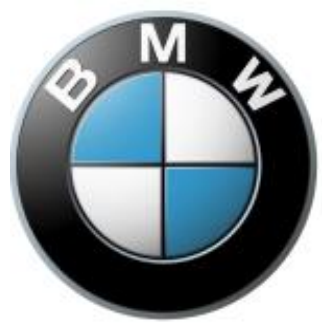

Merek Pengugat

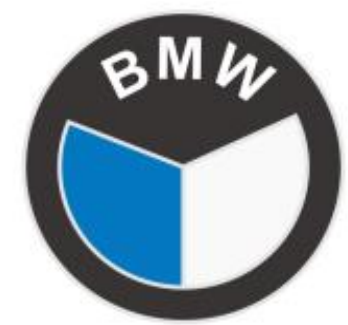

Merek Tergugat
Akibat belum ada Peraturan Pemerintah (PP) dalam hal ini Dirjen HKI, yang mengatur mengenai Persamaan pada pokoknya atau keseluruhan dengan merek terkenal untuk barang dan/atau jasa yang tidak sejenis pada saat kasus ini masih dalam proses persidangan. Maka terjadilah ketidakpastian hukum bagi pemegang merek terkenal. Akibat lain dari belum adanya PP pada saat itu, Hakim tidak selaras dalam memutus perkara dalam hal merek. Seperti kasus Giordano melawan Giordani di tingkat kasasi hakim mengaabulkan seluruh gugatan, menyatakan bahwa Giordano adalah merek terkenal dan Giordani mempunyai persamaan pada pokoknya dengan merek terkenal dan telah dilandasi dengan iktikad baik sehingga membaalkan merek Giordani. Sama halnya dengan kasus Prada SA vs The Rich Prada hakim mengabulkan gugtaan pembatalan merek yang dilayangkan ke The Rich Prada dengan pertimbangan bahwa ada kesamaan, sehingga dapat menyesatkan konsumen.

Lain halnya dengan kasus BMW vs BMW yang penulis bahas panjang lebar ini, hakim 
tidak mengikuti yurisprudensi dari kasus serupa, karena keluarnya SEMA yang memerintahkan hakim untuk memberikan amar putusan tidak dapat diterima untuk kasus persamaan pada pokoknya dan/atau seluruhnya merek terkenal tidak sejenis, sehingga putusan-putusan sebelumnya tidak dapat dipedomani. Sehingga putusan PK Kabul dengan amar putusan tidak diterima. Inkonsitensi putusan hakim ini menimbulkan ketidakpastian dan ketidakadilan hukum untuk para pemegang hak merek terkenal, yang sudah susah payah, bekerja keras untuk membangun mereknya hingga terkenal dengan reputasi yang baik.

Permasalahan kekosongan hukum yang mengatur lebih rinci dalam PP mengenai persamaan pada pokoknya atau keseluruhan merek terkenal tidak sejenis yang belum diatur dalam Undang-Undang Nomor 15 Tahun 2001 Tentang Merek. Sekarang dalam UndangUndang Nomor 20 Tahun 2016 Tentang Merek dan Indikasi Geografis yang baru telah diatur persayaratan tertentu mengenai persamaan pada pokoknya atau keseluruhan merek terkenal tidak sejenis dalam Peraturan Menteri Hukum dan Hak Asasi Manusia Republik Indonesia (PermenkumhamRI) Nomor 67 Tahun 2016, dalam Pasal 19 ayat (3) dan (4), berbunyi:

(1) "Persyaratan tertentu sebagaimana dimaksud pada ayat (2) meliputi: a. adanya keberatan yang diajukan seara tertulis oleh pemilik Merek terkenal terhadap Permohonan; dan b. Merek terkenal sudah terdaftar.

(2) Keberatan sebagaimana dimaksud pada ayat (3) huruf a harus memuat alasan disertai bukti yang cukup bahwa Permohonan oleh pihak lain tersebut mempunyai persamaan pada pokoknya atau keseluruhanya untuk barang dan/atau jasa yang tidak sejenis dengan merek milik pemohon kebertan yang dimohonkan oleh pihak lain merupakan terkenal."

Adanya peraturan baru ini diharapkan dapat lebih menjamin kepastian hukum yang berkeadilan untuk pemegang merek terkenal dan bisa menjadi pedoman para hakim untuk memutus perkara agar terjadi keseragaman dalam memutus perkara yang sama.

$\begin{array}{lrrr}\text { Putusan Mahkamah } & \text { Agung } & \text { Nomor } \\ \text { 29PK/Pdt.Sus-HKI/2016 } & \text { yang } & \text { sudah }\end{array}$
berkekuatan hukum tetap dengan amar putusan tidak dapat diterima. Berkaitan dengan putusan perkara tersebut tidak ada akibat hukum atau konseskuensi terhadap status kepemilikan objek perkara dalam hal ini Penggugat tidak dapat membatalkan merek BMW milik Tergugat sehingga pihak Terguggat masih bisa menggunakan merek tersebut. Maka atas hal tersebut objek sengketa pun tidak mengalami perubahan status apapun, sedangkan posisi hukum dari para pihak masih seperti semula sebelum terjadinya sengketa merek antara Penggugat dan Tergugat. 


\section{PENUTUP}

\section{Kesimpulan}

1. Putusan Majelis Hakim kurang tepat

Putusan Mahkamah Agung Nomor 29 PK/Pdt.Sus-HKI/2016 mengenai gugatan BMW (BAYERISCHE MOTOREEN WERKE AKTIENGESELOLSCHAFFT) terhadap BMW (BODY MAN WEAR) kurang tepat. Dengan dikeluarkanya Surat Edaran Mahkamah Agung Nomor 03/BUA.6/H.S/SP/XII/2015,

mengakibatkan amar putusan untuk gugatan persamaan pada pokoknya dan/atau keseluruhan merek terkenal tidak sejenis, harus diputus dengan amar tidak dapat diterima. Majelis hakim berpendapat bahwa belum ada aturan yang mengatur untuk kasus persamaan merek beda jenis, sehingga dianggap belum ada pelanggaran hukum. Menurut penulis dengan amar putusan tersebut dapat menimbulakan ketidakpastian hukum untuk pemegang merek terkenal dalam hali ini BMW milik Penguggat yang sudah terbukti terkenal di dunia.

Padahal Sejatinya merek berfungsi sebagai ciri dan daya pembeda bagi setiap produk yang diproduksi, terkhusus merek terkenal yang sudah memiliki konsumen yang begitu luas, hasil dari promosi yang gencar dan besar-besaran dan seharusnya proses pendaftaran merek dilakukan dengan iktikad baik dan harus memiliki unsur pembeda sebagaimana diatur dalam Pasal 5 huruf a dan b Undang-Undang Nomor 15 Tahun 2001 tentang Merek dan peraturan merek yang baru dalam Pasal 20 UndangUndang Nomor 20 Tahun 2016 tentang Merek dan Indikasi Geografis. Tetapi BMW milik Tergugat disini telah melakukan iktikad tidak baik dalam pendaftaranya terbukti dengan adanya persamaan merek pada pokoknya mulai dari pengucapan serta bentuk logo, sehingga tidak memiliki daya pembeda yang terlihat jelas, dan jelas pula ini merupakan pendomplengan terhadap merek terkenal BMW milik Pengugat.

2. Akibat hukum Putusan Mahkamah Agung Nomor 29 PK/Pdt.SusHKI/2016 yang diputus dengan amar putusan tidak dapat diterima dalam upaya hukum terakhir PK, sudah berkukuatan hukum tetap. Sehingga tidak ada akibat hukum untuk kedua belah pihak, seolah-olah belum ada pelanggaran yang terjadi. Penggugat tidak bisa membatalkan merek BMW yang digunakan oleh Tergugat dan Tergugat dapat terus menggunakan merek BMW walaupun terdapat unsur persaamaan merek dan pendomplengan merek terkenal bahkan iktikad tidak baik yang dilakukan oleh Tergugat. Jadi, objek sengketa pun tidak 
mengalami perubahan status apapun, sedangkan posisi hukum dari para pihak masih seperti semula sebelum terjadinya sengketa merek antara Penggugat dan Tergugat. Dengan begitu kedua belah pihak sama-sama memiliki hak ekseklusif atas merek BMW mereka masing-masing. Tetapi pemegang merek terkenal pasti dirugikan dalam hal ini merek BMW milik Penggugat. Karena merek BMW milik Tergugat masih bisa tetap beredar di pasaran dan dilindungi juga oleh undangundang. Sehingga dapat menyesatkan konsumen, yang mengira ada keterkaitan antara merek Penggugat dan Tergugat.

\section{DAFTAR PUSTAKA}

\section{Buku}

Adrian Sutedi. 2009. Hak Atas Kekayaan Intelektual. Jakarta: Sinar Grafika.

Agung Indriyanto dan Irnie Mela Yusnita. 2017. Aspek Hukum Pendaftaran Merek. Jakarta: PT RajaGrafindo Persada.

Anne Gunawati. 2015. Pelindungan Merek Terkenal Barang dan Jasa Tidak Sejenis Terhadap Persaingan Usaha Tidak Sehat. Cetakan ke-1. Bandung: PT. Alumni.

H. OK. Saidin. 2015. Aspek Hukum Hak Kekayaan Intelektual. Cetakan ke-9. Jakarta: PT. Raja Grafindo Persada.

M. Yahya Harahap. 1996. Tinjauan Merek Secara Umum dan Hukum Merek di Indonesia Berdasarkan Undang-Undang
Nomor 19 Tahun 1992. Bandung: PT. Citra Aditya Bakti.

O.C. Kaligis. 2012. Teori-Praktik Merek dan Hak Cipta. Bandung: PT. Alumni.

Titon Slamet Kurnia. 2011. Perlindungan HUkum Terhadap Merek Terkenal di Indonesia Pasca Trips. Bandung: PT. Alumni.

\section{Peraturan Perundang-Undangan}

Undang-Undang Nomor 15 Tahun 2001 Tentang Merek

Undang-Undang Nomor 20 Tahun 2016 tentang Merek dan Indikasi Geografis

Peraturan Menteri Hukum dan Hak Asasi Manusia Republik Indonesia Nomor 67 Tahun 2016

\section{PUTUSAN PENGADILAN}

Putusan Mahkamah Agung Nomor 29 PK/Pdt.Sus-HKI/2016

\section{Data Eletronik}

https://beritagar.id/artikel-

amp/berita/baju-bmw-penjaringankalahkan-mobilbmw-dalam-sengketamerek-di-ma

https://m.detik.com/news/berita/3274107 /sengketa-merek-mobil-bmw-kalahlawanbaju-bmw-dari-penjaringan 